\title{
\begin{tabular}{l|l} 
Mibraries & DSpace@MIT
\end{tabular}
}

\author{
MIT Open Access Articles
}

\section{Polyvalent Oligonucleotide Gold Nanoparticle Conjugates as Delivery Vehicles for Platinum(IV) Warheads}

The MIT Faculty has made this article openly available. Please share how this access benefits you. Your story matters.

Citation: Dhar, Shanta, Weston L. Daniel, David A. Giljohann, Chad A. Mirkin, and Stephen J. Lippard. "Polyvalent Oligonucleotide Gold Nanoparticle Conjugates as Delivery Vehicles for Platinum(IV) Warheads." Journal of the American Chemical Society 131, no. 41 (October 21, 2009): 14652-14653.

As Published: http://dx.doi.org/10.1021/ja9071282

Publisher: American Chemical Society (ACS)

Persistent URL: http://hdl.handle.net/1721.1/82149

Version: Author's final manuscript: final author's manuscript post peer review, without publisher's formatting or copy editing

Terms of Use: Article is made available in accordance with the publisher's policy and may be subject to US copyright law. Please refer to the publisher's site for terms of use. 


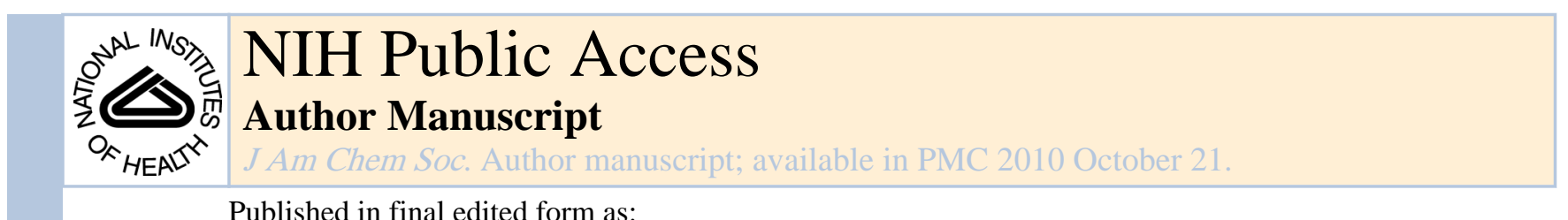

J Am Chem Soc. 2009 October 21; 131(41): 14652-14653. doi:10.1021/ja9071282.

\title{
Polyvalent Oligonucleotide Gold Nanoparticle Conjugates as Delivery Vehicles for Platinum(IV) Warheads
}

\author{
Shanta Dhar ${ }^{\dagger}$, Weston L. Daniel ${ }^{\ddagger}$, David A. Giljohann ${ }^{\ddagger}$, Chad A. Mirkin ${ }^{\star} \neq$, and Stephen J. \\ Lippard ${ }^{*}$, \\ † Department of Chemistry, Massachusetts Institute of Technology, Cambridge, Massachusetts \\ 02139 \\ ‡ Department of Chemistry and International Institute for Nanotechnology, Northwestern \\ University, 2145 Sheridan Road, Evanston, Illinois 60208-3113
}

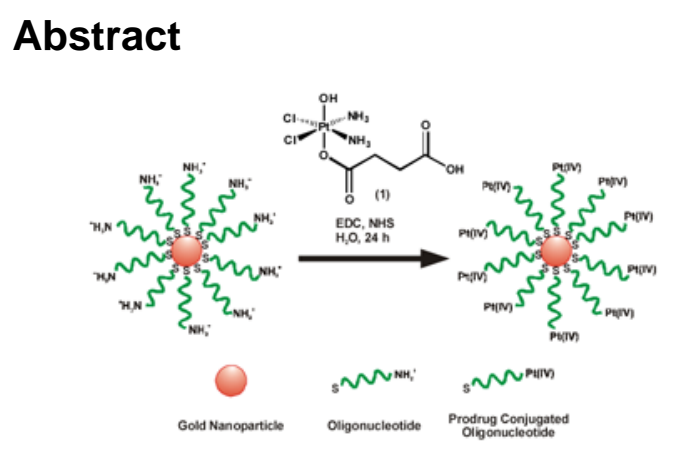

Amine-functionalized polyvalent oligonucleotide gold nanoparticles (DNA-Au NP) were derivatized with a cisplatin prodrug, and the resulting DNA-Au NP conjugates were used to internalize multiple platinum centers. A platinum(IV) complex, $c, c, t-\left[\mathrm{Pt}\left(\mathrm{NH}_{3}\right)_{2} \mathrm{Cl}_{2}(\mathrm{OH})\right.$ $\left.\left(\mathrm{O}_{2} \mathrm{CCH}_{2} \mathrm{CH}_{2} \mathrm{CO}_{2} \mathrm{H}\right)\right]$, was tethered to the surface of DNA-Au NPs through amide linkages. The platinum-tethered gold nanoparticles (Pt-DNA-Au NPs) were taken into several cancer cells. The drop in intracellular $\mathrm{pH}$ facilitated reductive release of cisplatin from the prodrug, which then formed 1,2-d(GpG) intrastrand cross-links in the cell nuclei as confirmed by an antibody specific for this adduct. The cytotoxicity of the platinum(IV) complex increases significantly in several cancer cell lines when the complex is attached to the surface of the DNA-Au NPs and in some instances exceeds that of cisplatin.

\begin{abstract}
The clinical success of cisplatin1,2 has been a major impetus for the evolution of a family of platinum anticancer drugs. Cisplatin and its analog carboplatin are among the most commonly used antitumor drugs today.3 Cisplatin is highly effective in the treatment of testicular and ovarian cancers and is widely employed for managing bladder, cervical, head and neck, oesophageal, and small-cell lung cancer. Like other chemotherapeutic agents, cisplatin has side effects including kidney toxicity, nausea, hearing impairment, and irreversible peripheral nerve damage.4-6 Synthetic delivery systems have great potential for overcoming problems associated with systemic toxicity that accompanies chemotherapy, including platinum-based treatment.7 Finding successful candidates and strategies for the
\end{abstract}

lippard@mit.edu; chadnano@northwestern.edu.

Supporting Information Available: Experimental details for the synthesis and characterization of platinum complexes, DNA-Au NPs, Pt-DNA-Au NPs, electrochemical studies, and in vitro cellular studies. This material is available free of charge via the internet at http://pubs.acs.org. 
delivery of platinum anticancer drugs has been a subject of extensive research. To reduce side effects and target tumor tissue, we 8-10 and others 11,12 have been investigating a variety of nanoparticulate delivery vehicles over the past several years. Polyvalent oligonucleotide gold nanoparticle conjugates (DNA-Au NPs) have appealing properties for drug delivery applications, including high cellular uptake in a variety of cell types, no demonstrated toxicity inherent to the conjugate, and resistance to enzymatic degradation.1315

$\mathrm{Pt}(\mathrm{IV})$ complexes provide an attractive alternative to $\mathrm{Pt}(\mathrm{II})$ compounds because their inertness results in fewer side effects. Pt(II)-based anticancer drugs are associated with higher reactivity and thus lower biological stability. Pt(IV) complexes are reduced in the intracellular milieu to yield the cytotoxic Pt(II) species through reductive elimination of axial ligands.16 Thus, $\mathrm{Pt}(\mathrm{IV})$ complexes provide an attractive alternative to the existing portfolio of Pt(II) drugs.

In the present work we have combined the properties of DNA-Au NPs and Pt(IV) prodrugs into a single agent for drug delivery. DNA-Au NPs were synthesized, characterized, and tested in vitro as carriers for Pt(IV) prodrugs. The Au NPs used in this study were functionalized with thiolated 28mer oligonucleotides containing a terminal dodecyl amine for conjugation. We used $c, c, t-\left[\mathrm{Pt}\left(\mathrm{NH}_{3}\right)_{2} \mathrm{Cl}_{2}(\mathrm{OH})\left(\mathrm{O}_{2} \mathrm{CCH}_{2} \mathrm{CH}_{2} \mathrm{CO}_{2} \mathrm{H}\right)\right]$ (1) (Scheme 1), a $\mathrm{Pt}(\mathrm{IV})$ compound capable of being tethered to an amine-functionalized DNA-Au NP surface via amide linkages.17 Treatment of 1 with 1-ethyl-3-[3-dimethylaminopropyl]carbodiimide (EDC) and $\mathrm{N}$-hydroxysuccinimide (NHS) afforded its $\mathrm{N}$-succinimidyl ester. This activated compound readily formed amide linkages with the amines on the DNA-Au NP surface (Scheme 1), resulting in Pt(IV) loaded DNA-Au NP conjugates (Pt-DNA-Au NPs). The resulting particles were purified from excess 1 using $100 \mathrm{kDa}$ molecular weight cutoff ultracentrifugation filtration membranes. The Pt-DNA-Au NP conjugates were characterized by platinum atomic absorption spectroscopy, which showed that $98 \%$ of the DNA-Au NP amines were conjugated to platinum. Importantly, UV-vis spectroscopy of the Pt-DNA-Au NPs surface plasmon band confirmed that there is no aggregation of the particles after prodrug conjugation (Figure S1, Supporting Information).

The conjugate was designed to release a cytotoxic dose of cisplatin upon intracellular reduction. An ideal Pt(IV) complex should be sufficiently stable to travel through the blood stream until it reaches a tumor cell without decomposition. Once inside the cell, however, it should have an appropriate reduction potential such that it will be reduced and release its cytotoxic payload. Electrochemical studies of $\mathbf{1}$ revealed an irreversible reduction maximum, corresponding to loss of the axial ligands (Figures S2 and S3). At pH 7.4, the reduction potential of 1 when extrapolated to a $0.0 \mathrm{mVs}^{-1}$ scan rate is $-0.49 \mathrm{~V}$. At $\mathrm{pH} 6.0$, a value similar to that reported for endosomes, 18 there is a positive shift of its reduction potential to $-0.42 \mathrm{~V}$, indicating that the acidic environment in cancer cells will facilitate reduction of the complex. The conjugation of $\mathbf{1}$ to the Au NP surface via an amide bond is not expected to significantly alter the reduction potential of the $\operatorname{Pt}(\mathrm{IV})$ center.

The ability of Pt-DNA-Au NPs to enter cells was investigated by fluorescence microscopy using particles functionalized with a mixed monolayer of platinated oligonucleotide strands and $5^{\prime}$ dye (Cy5) labeled strands. The conjugates were incubated with cells for varying periods of time. After $6 \mathrm{~h}$, the conjugates had locaserved in the cytosol (Figure 1B). Oregon Green 488R taxol bis acetate, which stains microtubules, indicated colocalization of these conjugates with the microtubules in HeLa cells. (Figure 1C).

In order to investigate the efficacy of Pt-DNA-Au NPs, we measured their ability to kill cancer cells of various origin. An MTT assay was applied to measure cytotoxicity induced 
by Pt-DNA-Au NPs and the activity was compared to those of free cisplatin and the parent $\mathrm{Pt}(\mathrm{IV})$ compound 1. Cytotoxicity profiles of Pt-DNA-Au NPs in human lung carcinoma A549, human prostate cancer PC3, cervical cancer HeLa, and human osteosarcoma U2OS cells are shown in Figure 2. After a $72 \mathrm{~h}$ treatment with different concentrations of Pt-DNAAu NPs, significant cytotoxicity was observed in all four cells lines. In A549 cells, cisplatin has an $\mathrm{IC}_{50}$ of $11 \mu \mathrm{M}$, whereas that of the Pt-DNA-Au NP is $0.9 \mu \mathrm{M}$, indicating the superior killing ability of this conjugate compared to cisplatin for this cell type. The Pt-DNA-Au NP construct has an $\mathrm{IC}_{50}$ value of $3.4 \mu \mathrm{M}$, comparable to that of cisplatin $\left(\mathrm{IC}_{50}, 5.1 \mu \mathrm{M}\right)$, in U2OS cells. Similarly, in HeLa and PC3 cells, Pt-DNA-Au NP (IC I0 $_{5}$ values 6.0 and $2.5 \mu \mathrm{M}$, respectively) reflect activity greater than that of cisplatin ( $\mathrm{IC}_{50}$ values 9.4 and $4.6 \mu \mathrm{M}$, respectively). The parent prodrug 1 did not show any significant killing under the same conditions. The enhanced activity of the Pt(IV) compound when tethered to a DNA-Au NP is an important finding of this study.

Since the anticancer activity of cisplatin derives from the formation of intrastrand 1,2$\mathrm{d}(\mathrm{GpG})$ cross-links on nuclear DNA, we investigated whether the platinum released following reduction of Pt-DNA-Au NP leads to this signature event by using a monoclonal antibody R-C18 specific for the adduct.19 After a $48 \mathrm{~h}$ incubation of Pt-DNA-Au NPs (1 $\mu \mathrm{M})$ with HeLa cells, the formation of 1,2-d(GpG) intrastrand cross-links was observed by antibody-derived green fluorescence in the cell nuclei (Figure S5), confirming formation of $\mathrm{Pt}(\mathrm{II})$ 1,2-d(GpG) intrastrand cross-links.

In conclusion, we devised a method of attaching and delivering platinum compounds using DNA-Au NPs. We demonstrate that a Pt(IV) complex, which is otherwise inactive, can be made active against several cancer cell lines when attached to DNA-Au NPs. These conjugates are internalized by cells and reduced to release cisplatin, which enters the nucleus and forms 1,2-d(GpG) intrastrand cross-links with DNA. Pt-DNA-Au NPs are more effective than cisplatin in killing cancer cells of several kinds. Future work will focus on the use of Pt prodrug and oligonucleotide conjugated Au NPs as a single agent for combination therapies. The use of DNA- or RNA-Au NPs20 to knockdown gene expression, should further improve the efficacy of these conjugates.

\section{Supplementary Material}

Refer to Web version on PubMed Central for supplementary material.

\section{Acknowledgments}

This work was supported by the NCI under grant CA034992, and 5U54CA11934 Centers of Cancer Nanotechnology Excellence (CCNEs). SD is grateful to the Koch Institute for Integrative Cancer Research for financial support. We thank Dr. Jurgen Thomale, University of Duisburg-Essen Hufelandstr, Germany for a gift of the R-C18 antibody.

\section{References}

1. Jamieson ER, Lippard SJ. Chem Rev. 1999; 99:2467-2498. [PubMed: 11749487]

2. Rosenberg B, VanCamp L, Trosko JE, Mansour VH. Nature. 1969; 222:385-6. [PubMed: 5782119]

3. Galanski M, Jakupec MA, Keppler BK. Curr Med Chem. 2005; 12:2075-2094. [PubMed: 16101495]

4. Hartmann JT, Kollmannsberger C, Kanz L, Bokemeyer C. Int J Cancer. 1999; 83:866-9. [PubMed: 10597214]

5. Laurell G, Jungnelius U. Laryngoscope. 1990; 100:724-34. [PubMed: 2362532]

6. Thompson SW, Davis LE, Kornfeld M, Hilgers RD, Standefer JC. Cancer. 1984; 54:1269-75. [PubMed: 6088023] 
7. Haxton KJ, Burt HM. J Pharm Sci. 2009; 98:2299-2316. [PubMed: 19009590]

8. Dhar S, Gu FX, Langer R, Farokhzad OC, Lippard SJ. Proc Natl Acad Sci U S A. 2008; 105:1735617361. [PubMed: 18978032]

9. Dhar S, Liu Z, Thomale J, Dai H, Lippard SJ. J Am Chem Soc. 2008; 130:11467-11476. [PubMed: 18661990]

10. Feazell RP, Nakayama-Ratchford N, Dai H, Lippard SJ. J Am Chem Soc. 2007; 129:8438-8439. [PubMed: 17569542]

11. Rieter WJ, Pott KM, Taylor KML, Lin W. J Am Chem Soc. 2008; 130:11584-11585. [PubMed: 18686947]

12. Sood P, Thurmond KB II, Jacob JE, Waller LK, Silva GO, Stewart DR, Nowotnik DP. Bioconjugate Chem. 2006; 17:1270-1279.

13. Giljohann DA, Seferos DS, Patel PC, Millstone JE, Rosi NL, Mirkin CA. Nano Lett. 2007; 7:3818-3821. [PubMed: 17997588]

14. Rosi NL, Giljohann DA, Thaxton CS, Lytton-Jean AKR, Han MS, Mirkin CA. Science. 2006; 312:1027-1030. [PubMed: 16709779]

15. Seferos DS, Prigodich AE, Giljohann DA, Patel PC, Mirkin CA. Nano Lett. 2009; 9:308-311. [PubMed: 19099465]

16. Giandomenico CM, Abrams MJ, Murrer BA, Vollano JF, Rheinheimer MI, Wyer SB, Bossard GE, Higgins JD. Inorg Chem. 1995; 34:1015-21. [PubMed: 20000850]

17. Di Pasqua AJ, Mishler RE, Ship YL, Dabrowiak JC, Asefa T. Mater Lett. 2009; 63:1876-1879.

18. Arunachalam B, Phan UT, Geuze HJ, Cresswell P. Proc Natl Acad Sci USA. 2000; 97:745-750. [PubMed: 10639150]

19. Liedert B, Pluim D, Schellens J, Thomale J. Nucleic Acids Res. 2006; 34:e47/1-e47/12. [PubMed: 16571898]

20. Giljohann DA, Seferos DS, Prigodich AE, Patel PC, Mirkin CA. J Am Chem Soc. 2009; 131:2072-2073. [PubMed: 19170493] 

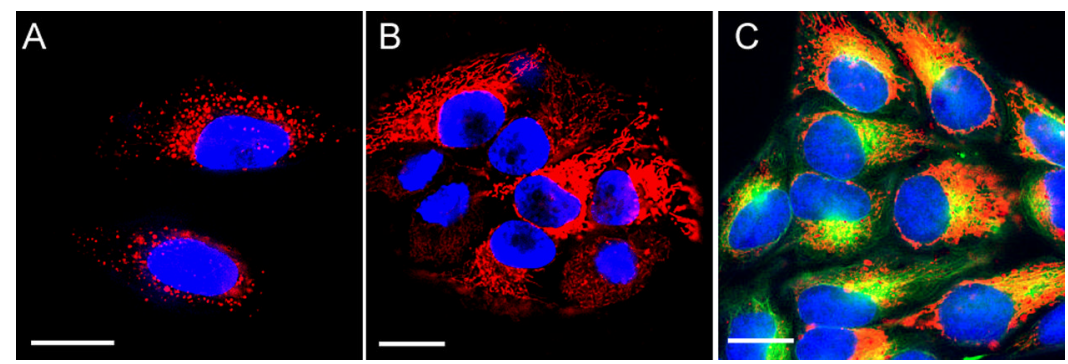

Figure 1.

Live cell imaging of HeLa cells upon incubation with platinum-tethered Cy5-DNA-Au NPs for $6 \mathrm{~h}(\mathrm{~A}), 12 \mathrm{~h}(\mathrm{~B})$, and colocalization of the particles with the cytoplasmic microtubules (C). Hoechst 33342 was used for nuclear staining. Scale bars: $20 \mu \mathrm{m}$. 

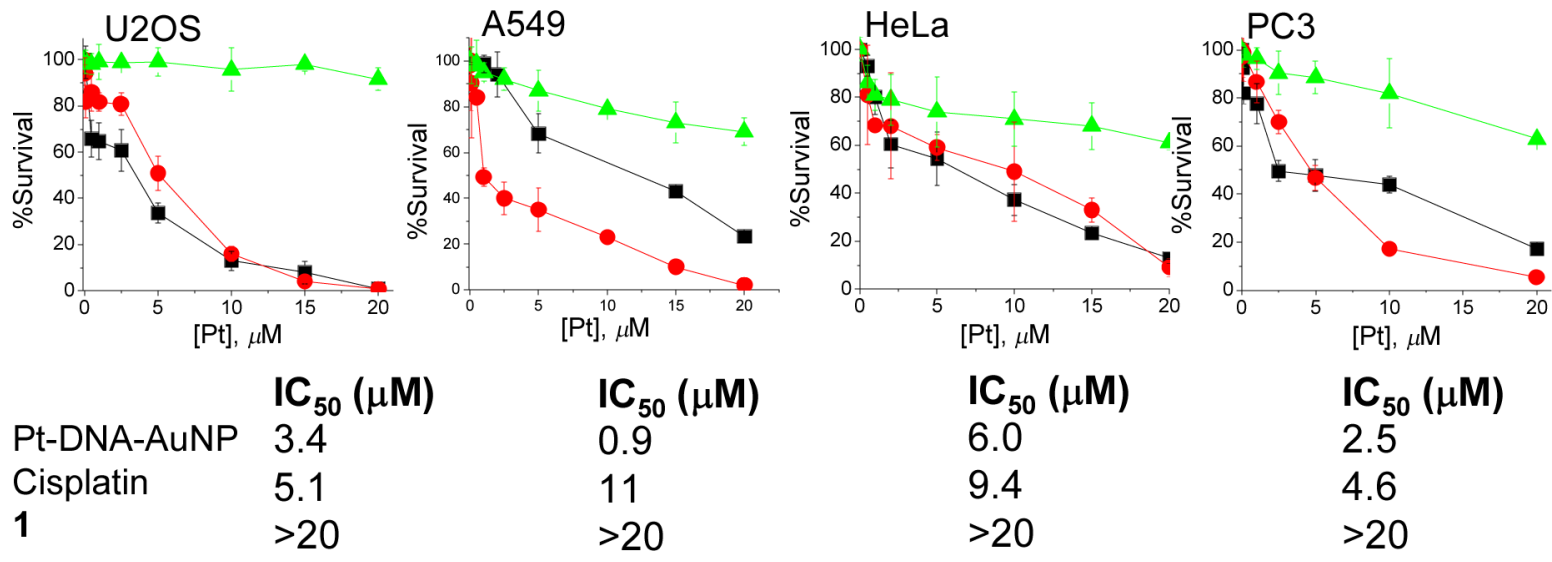

$\mathrm{IC}_{50}(\mu \mathrm{M})$

2.5

4.6

$>20$

Figure 2.

Cytotoxicity profiles of Pt-DNA-Au NP (•), cisplatin $(\square), 1(\Delta)$ with U2OS, A549, HeLa, and PC3 cells. 


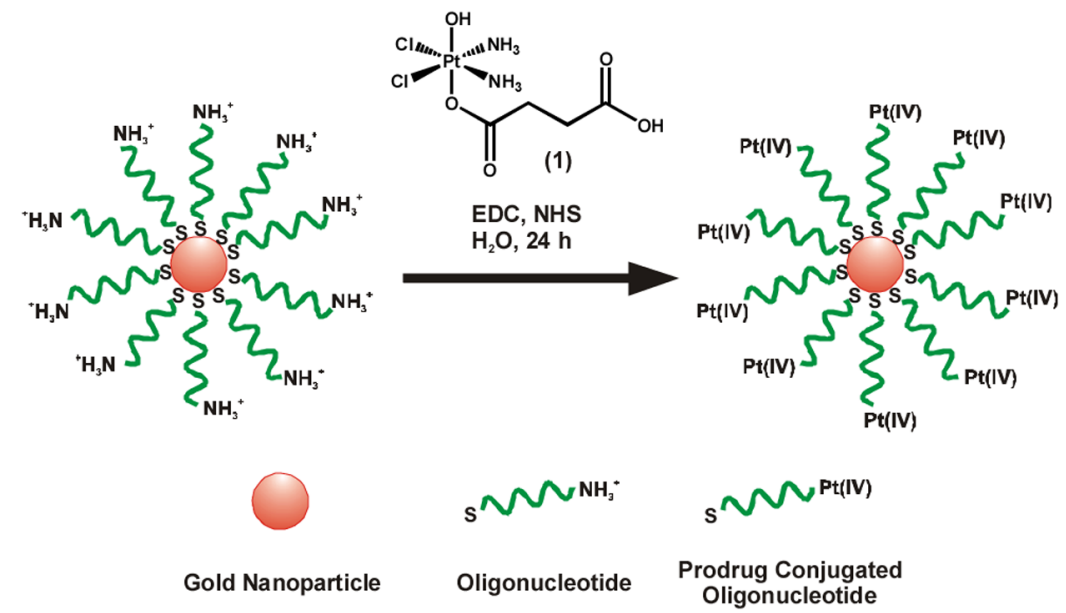

Scheme 1.

Construction of Pt-DNA-Au NP 